ISSN 2078-6441. Вісник Львівського університету. Серія географічна. 2013. Випуск 44. С. 257-264. Visnyk of the Lviv University. Series Geography. 2013. Issue 44. P. 257-264.

$631.4(477.8)$

\author{
іновій ньків \\ ьвівський н ціон льний університет імені в н \\ вул. . орошенк , 41, 79000, м. ввів, кр їн
}

ро н лізов но структуру грунтового покриву рп тського регіону кр їни, який з лучений для сільськогоспод рського землекористув ння, в тому числі під ріллю. ст новлено основні ет пи збільшення площі орних земель. пропонов но для визн чення ефективності сільськогоспод рського землекористув ння використовув ти комплексний підхід із використ нням просторових, пр вових, екологічних, економічних пок зників. ля х $\mathrm{p}$ ктеристики сільськогоспод рського типу використ ння земельного фонду обгрунтов но використ ння термін "грунтокористув ння".

лючові слов : продуктивні грунти, землекористув ння, рп тський регіон кр їни, грунтокористув ння.

рунтові ресурси пл нети, як і окремого регіону, сформув лися 3 б г то тисяч років до появи людини вн слідок сукупної дії чинників грунтоутворення (клім ту, гірської породи, рельєфу, живих орг нізмів) 3 зн чний період. моменту появи людини грунти розгляд ли як невіддільний елемент певної території, як м є своє розт шув ння, рельєф, рослинний світ, т використовув л ся як просторовий б зис для переміщення, будівництв стоянок i як територію, що г р нтув л з безпечення $\mathrm{x}$ рчового р ціону при суцільному домінув нні привл снюв льного землекористув ння (мисливств і збир льництв ). ізкі зміни природних умов після з кінчення льодовикового періоду, появ предст вників тв ринного і рослинного світу, що були корисними для людини т прид тними для доместик ції, ст ли стимулом до осілого способу життя і відтворюв льного землекористув ння, що д ло змогу більш продуктивніше використовув ти природні ресурси, відтворюв ти і примножув ти їхні можливості. ершим видом відтворюв льного землекористув ння було кочове скот рство, зорієнтов не н сезонне використ ння території без ур хув ння особливостей грунтового покриву, т 3 б г тством і різном нітністю тр в'яного рослинного покриву. т новлення осілого способу життя, перехід до землеробств ст ло в жливою віхою в розумінні зн чення і н м Г нні вивчення природи грунту - основного об'ЄКт пр ці т 3 собу виробництв в сільському і лісовому господ рстві, який був д ний людині без докл д ння дод ткових зусиль н його створення.

жливість і нез мінність грунтів у сільськогоспод рському, лісогоспод рському землекористув нні зумовлює зн чний інтерес до дослідження їхніх морфологічних особливостей, фізико-хімічних вл стивостей т виявлення впливу цих пок зників н особливості вирощув ння різних сільськогоспод рських культур, що висвітлено у великій кількості н укових публік цій. еоретичні т методологічні положення

(C) ньків ., 2013 
зн чення грунтів у сільськогоспод рському виробництві розкриті в пр цях . едведев , . ктіонової, . рупеніков, . ндрущенко, . озняк, . 3 ренк т ін.

ерші відомості про грунти походять від перших прирічкових землеробських цивіліз цій внього гипту, есопот мії, ндії, ит ю, ередньої зії. йд вніш якісн х р ктеристик сільськогоспод рських земель, д тов н 3500-3000 рр. до н.е., зберегл ся н єгипетських п пірус х і стел х (“ руклінський п пірус", “ одекс ммур пі”) [12]. пр цях нтичних грецьких і римських учених ( тон т ршого, ррон , лінія т ін.) з фіксов но перші спроби уз г льнення i теоретичного висвітлення емпіричних відомостей про грунти. же тоді вчені чітко розрізняли т кі поняття, як земля - ч стин космосу т грунт - верхній родючий ш р. оступово з поширенням відтворюв льного землекористув ння з роджув лися т поширюв лися зн ння про грунти, особливості їхнього використ ння.

р нніх ет п х для землеробств в меж х рп тського регіону, передусім, використовув ли люві льні грунти річкових долин иси, ністр , руту, хідного угу, що було зумовлено низкою причин:

- відсутність деревної рослинності, що лімітув л їхній обробіток;

- легким гр нулометричним скл д, що д в ло змогу обробляти їх дерев'яними зн ряддями (сох , р ло);

- щорічним відновленням родючості з вдяки регулярному з топленню;

- сприятливішими клім тичними умов ми.

ідсутність зн нь про природу грунтової родючості т н виків її відтворення змушув ло н селення з лиш ти висн жені, з бур'янені земельні ділянки т освоюв ти нові території з продуктивнішими грунт ми. кий спосіб ведення господ рств отрим в н зву “кочове землеробство”, що н йяскр віше виявився в трипільській культурі. рост ння кількості н селення, необхідність збільшення виробництв продуктів х рчув ння, удоскон лення зн рядь обробітку з умов існув ння общинної форми вл сності н землю стимулюв ло використ ння лісових грунтів у меж х ресурсної зони н селених пунктів. стосув ння підсічно-вогневої системи землеробств д ло змогу 3 лучити в ктивне сільськогоспод рське використ ння лісові (сірі, буроземи, дерновопідзолисті, дерново-к рбон тні) т опідзолені (темно-сірі, чорноземи опідзолені) грунти, які в ході еволюції пройшли як лісову, т к і степову ф зи грунтоутворення. ід ріллю, з звич й, використовув ли втоморфні грунти, які не м ли озн к постійного бо сезонного перезволоження, і в умов х н длишкового зволоження не відчув ли нест чі у зволоженні. півгідроморфні (лучні, дернові глейові) і гігроморфні (торфові, торфово-болотні) грунти з високим рівнем грунтових вод використовув ли як сінож ті т п совищ, оскільки для їхнього обробітку, передусім, необхідно було оптимізув ти водно-повітряний режим, відводячи н длишкові води. дн к домінув ння втоморфних грунтів і зн чні витр ти н освоєння перезволожених були перешкодою в їхньому використ нні. ідсутність н вичок відновлення родючості освоєних лісових грунтів, зрост ння кількості н селення, вичерп ність резерву неосвоєних земель у меж х ресурсної зони з домінув ння прив тної форми вл сності змушув ли поверт тись до покинутих земельних ділянок, де родючість грунтів відновил ся вн слідок природних процесів, і впров джуючи перелогову систему землеробств . корочення терміну перелогу до одного року зумовило впров дження прогресивнішої, п рової системи землеробств [10].

ерші спроби розділення грунтів рп тського регіону кр їни з якістю зроблені ще н поч тку XVI ст., коли окремі території входили до скл ду еликого нязівств 
итовського, під ч с проведення волочного реформув ння. сновним з вд нням реформи бул ліквід ція х отичності полів, д льноземелля в структурі фільв ркових і селянських господ рств, підвищення їхньої продуктивності з метою збільшення виробництв тов рного зерн . озміри волоки (від 33 до 50 моргів і більше), яку н д в ли в користув ння селянських господ рств, з леж ли від якості грунтів, які були розділені н три якісні к тегорії: добрий, середній і пог ний (“подлый”) $[5,8]$. кість грунтів т кож вр ховув ли, визн ч ючи розмір земельного под тку.

од льше відчутне збільшення площі сільськогоспод рських земель ун слідок вирубув ння лісів і розорюв ння природних лук відбулося впродовж к піт лістичного ет пу землекористув ння (після ск сув ння кріпосного пр в 1848 р.), що було зумовлене розширенням ринків сільськогоспод рської продукції, збільшенням ч стки виробництв тов рної продукції в господ рств х, удоскон ленням зн рядь обробітку землі й систем землеробств . ч с р дянського ет пу землекористув ння, для якого х р ктерний дміністр тивно-ком ндний стиль упр вління, екстенсивні методи використ ння природних ресурсів, у тім числі й земельних, тот льне домінув ння колгоспно-р дгоспної моделі в сільському господ рстві з гострої потреби збільшення виробництв сільськогоспод рської продукції відбулося чергове м сшт бне розширення площ сільськогоспод рських земель розорюв нням прибережних з хисних смуг, схилів, меліор ції н длишково зволожених земель, що зумовило досягнення н йбільших пок зників сільськогоспод рської освоєності т розор ності в рп тському регіоні кр їни.

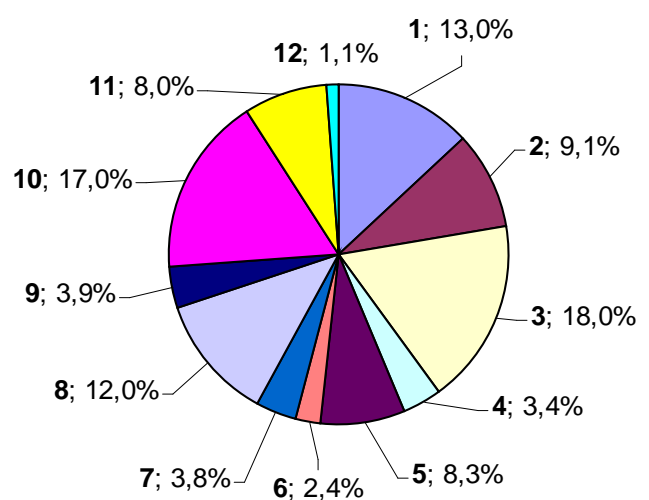

ис. 1. труктур грунтів рп тського регіону кр їни, з лучених у сільськогоспод рське землекористув ння: 1 - дерново-підзолисті, у тім числі оглеєні; 2 - сірі лісові, у тім числі оглеєні; 3 - опідзолені грунти, у тім числі оглеєні; 4 - чорноземи, у тім числі к рбон тні; 5 - лучні; 6 - лучно-болотні; 7 - болотні, торфово-болотні, торфові; 8 - дернові; 9 - буроземно-підзолисті; 10 - бурі гірсько-лісові; 11 - дерново-буроземні; 12 - інші. оступов інтенсифік ція землекористув ння, особливо сільськогоспод рського, привел до того, що в 1990-х рок х, у рп тському регіоні для ведення сільського господ рств було з лучено 3 097,7 тис. г , пок зник сільськогоспод рської освоєності території регіону ст новив 54,7\% [6] ля створення сільськогоспод рських угідь у регіоні 3 весь період ст новлення відтворюв льного землекористув ння було тр нсформов но близько 1,9 млн г лісових земель, 3 яких 1,1 млн г використовують під ріллю. лучення лісових грунтів в екстенсивне сільськогоспод рське виробництво спричинило погіршення їхніх морфологічних особливостей, фізико-хімічних вл стивостей і розвиток низки дегр д ційних процесів. пецифік чинників грунтоутворення, розт шув ння в меж $\mathrm{x}$ регіону кр їнських рп т зумовили те, що н йбільш ктивно в сільськогоспод рське землекористув ння були з лучені опідзолені грунти (темно-сірі і чорноземи; 18,0\%), бурі гірсько-лісові $(17,0)$, дерново-підзолисті $(13,0)$ т дернові $(12,0$ \%) (див. т блицю, рис. 1). 
рунти рп тського регіону кр їни,

з лучені до сільськогоспод рського землекористув ння [1-4]

\begin{tabular}{|c|c|c|c|c|c|c|c|c|c|c|c|c|c|c|c|c|c|c|c|c|}
\hline \multirow[b]{2}{*}{ рунти } & \multicolumn{4}{|c|}{ ьвівськ обл. } & \multicolumn{4}{|c|}{$\begin{array}{l}\text { в но- } \\
\text { p нківськ } \\
\text { обл. }\end{array}$} & \multicolumn{4}{|c|}{$\begin{array}{l}\text { К рп тсьК } \\
\text { обл. }\end{array}$} & \multicolumn{4}{|c|}{ ернівецьк обл. } & \multicolumn{4}{|c|}{$\begin{array}{l}\text { рп тський } \\
\text { регіон }\end{array}$} \\
\hline & 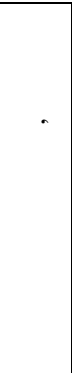 & 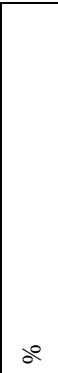 & 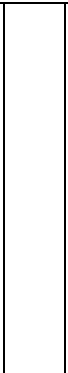 & 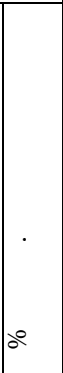 & 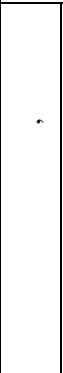 & 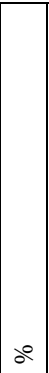 & 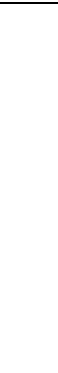 & 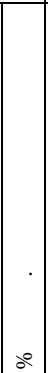 & 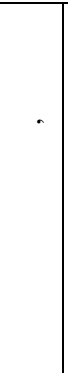 & 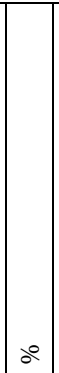 & 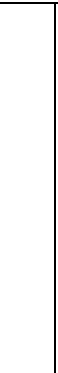 & 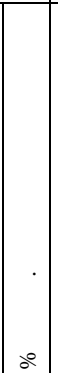 & 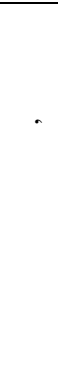 & 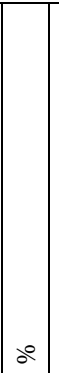 & 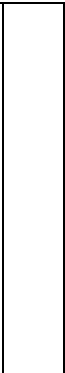 & 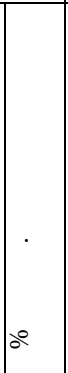 & 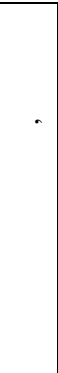 & 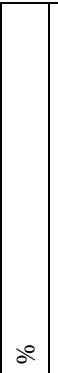 & 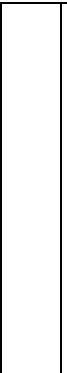 & 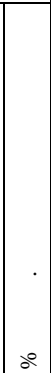 \\
\hline $\begin{array}{c}\text { ерново- } \\
\text { підзолисті, у } \\
\text { тім числі } \\
\text { оглеєні }\end{array}$ & 234,8 & 17,3 & 150,1 & 20,3 & 102,7 & 15,6 & 48,9 & 14,1 & 9,2 & 1,6 & 6,1 & 3,8 & 57,0 & 11,3 & 16,2 & 5,4 & 403,7 & 13,0 & 221,3 & $\mid 14,3$ \\
\hline $\begin{array}{l}\text { iрi лісові, у } \\
\text { тім числі } \\
\text { оглеєні }\end{array}$ & 137,7 & 10,1 & 108,0 & 14,6 & 33,8 & 5,1 & 20,3 & 5,9 & - & - & - & - & 110,7 & 22,1 & 75,6 & 25,0 & 282,2 & 0,1 & 203,9 & 13,1 \\
\hline $\begin{array}{c}\text { підзолені } \\
\text { грунти, у тім } \\
\text { числі оглеєні }\end{array}$ & 221,8 & 16,2 & 197,5 & 26,7 & 160,5 & 24,5 & 150,6 & 43,4 & - & - & - & - & 176,1 & 35,0 & 150,4 & 49,7 & 358,4 & 48,0 & 498,5 & 32,1 \\
\hline $\begin{array}{c}\text { орноземи, у } \\
\text { тім числі } \\
\text { к рбон тні }\end{array}$ & 74,8 & 5,5 & 71,0 & 9,6 & 14,6 & 2,2 & 12,7 & 3,6 & - & - & - & - & 15,7 & 3,1 & 13,9 & 4,6 & 105,1 & 3,4 & 97,6 & 6,3 \\
\hline $\begin{array}{c}\text { учно- } \\
\text { чорноземні } \\
\end{array}$ & 7,4 & 0,5 & 5,2 & 0,7 & 3,9 & 0,6 & 2,2 & 0,6 & - & - & - & - & 2,5 & 0,5 & 1,6 & 0,5 & 13,8 & 0,4 & 9,0 & 0,6 \\
\hline учні & 150,4 & $1, .0$ & 54,4 & 7,3 & 55,1 & 8,4 & 32,3 & 9,3 & 14,1 & 2,4 & 5,0 & 3,1 & 37,3 & 7,4 & 23,2 & 7,7 & 256,9 & 8,3 & 114.9 & 7,4 \\
\hline учно-болотні & 48,4 & 3,6 & 2,4 & 0,3 & 8,7 & 1,3 & 1,3 & 0,4 & 3,6 & 0,6 & - & - & 13,6 & 2,7 & 3,9 & 1,3 & 74,3 & 2,4 & 7,6 & 0,5 \\
\hline $\begin{array}{c}\text { олотні, } \\
\text { торфово- } \\
\text { болотні } \\
\text { торфові }\end{array}$ & 99,3 & 7,3 & 1,5 & 0,3 & 15,5 & 2,4 & 1,7 & 0,5 & 0,5 & 0,1 & - & - & 2,8 & 0,6 & 0,4 & 0,1 & 118,1 & 3,8 & 3,6 & 0,2 \\
\hline ернові & 136,6 & 10,0 & 74,5 & 10,0 & 65,4 & 10,0 & 34,3 & 9,9 & 135,2 & 23,4 & 86,0 & 53,6 & 34,9 & 6,9 & 15,5 & 5,1 & 372,1 & \begin{tabular}{|l|l}
42,0 \\
\end{tabular} & 210,3 & 13,6 \\
\hline $\begin{array}{c}\text { уроземно- } \\
\text { підзолисті }\end{array}$ & 11,9 & 0,9 & 6,7 & 0,9 & 38,2 & 5,8 & 16,7 & 4,8 & 61,5 & 10,6 & 20,9 & 13,0 & 11,0 & 2,2 & 0,7 & 0,2 & 122,6 & 3,9 & 45,0 & 2,9 \\
\hline $\begin{array}{l}\text { урі гірсько- } \\
\text { лісові } \\
\end{array}$ & 199,4 & 14,6 & 51,5 & 6,9 & 77,0 & 11,7 & 6,9 & 2,0 & 236,0 & 40,9 & 17,7 & 11,0 & 10,8 & 2,1 & 0,4 & 0,1 & 523,2 & 17,0 & 76,5 & 4,9 \\
\hline $\begin{array}{r}\text { ерново- } \\
\text { буроземні }\end{array}$ & 33,2 & 2,4 & 15,4 & 2,1 & 77,4 & 11,8 & 17,7 & 5,1 & 105,8 & 18,3 & 19,6 & 12,2 & 30,3 & 6,0 & 0,7 & 0,2 & 246,7 & 8,0 & 53,4 & 3,4 \\
\hline $\begin{array}{c}\text { учно- } \\
\text { буроземні }\end{array}$ & 7,0 & 0,5 & 2,4 & 0,3 & 3,0 & 0,5 & 1,7 & 0,5 & 11,6 & 2,0 & 5,2 & 3,2 & - & - & - & - & 21,6 & 0,7 & 9,3 & 0,6 \\
\hline сього & 1362,7 & 100 & 740,6 & 100 & 655,8 & 100 & 347,3 & 100 & 577,5 & 100 & 160,4 & 100 & 502,7 & 100 & 302,5 & 100 & 3098,7 & \begin{tabular}{|l|l|}
100 & 1 \\
\end{tabular} & 1550,9 & 100 \\
\hline
\end{tabular}

собливості розт шув ння т співвідношення чинників грунтоутворення в меж $\mathrm{x}$ обл стей, що входять до скл ду рп тського регіону, визн чили певні відмінності в структурі грунтів, з лучених до сільськогоспод рського землекористув ння. кщо в

к рп тській обл. домінують бурі гірсько-лісові $(40,9 \%)$ т дернові $(23,4)$, то в 
ернівецькій - опідзолені $(35,0)$, сірі лісові $(22,1)$, дерново-підзолисті $(11,3 \%)$ грунти.

меж х в но- р нківської обл сті н й ктивніше у сільськогоспод рське землекористув ння з лучені опідзолені т сірі лісові грунти рут- ністерського межиріччя й пілля $(24,5 \%)$, дерново-підзолисті грунти ередк рп ття $(15,6)$ т бурі гірсько-лісові, дерновобуроземні грунти рп т (близько 12,0\%). ьвівській обл. під сільськогоспод рські землі, головно, використовують дерново-підзолисті грунти лого олісся і ередк рп ття $(17,3 \%)$, опідзолені грунти пілля, олинської і янсько- ністерської височини $(16,2)$, бурі гірсько-лісові грунти рп т 14,6 \%) (див. т блицю).

йпродуктивніші грунти, які м ють зн чну потужність гумусового горизонту, високий вміст гумусу і поживних речовин, оптим льні водно-фізичні вл стивості, використовують під ріллею. меж х рп тського регіону кр їни розор но близько $50 \%$ освоєних грунтів. йбільш ч стк розор них грунтів х $\mathrm{p}$ ктерн для ернівецької $(60,2 \%)$, н йменш - для к рп тської $(27,8 \%)$ обл стей. ок зник розор ності

рп тського регіону кр їни ст ном н 1990 р. ст новив близько 26,6\%. труктур освоєних грунтів регіону, які використовують під ріллею, пок з н н рис. 2.

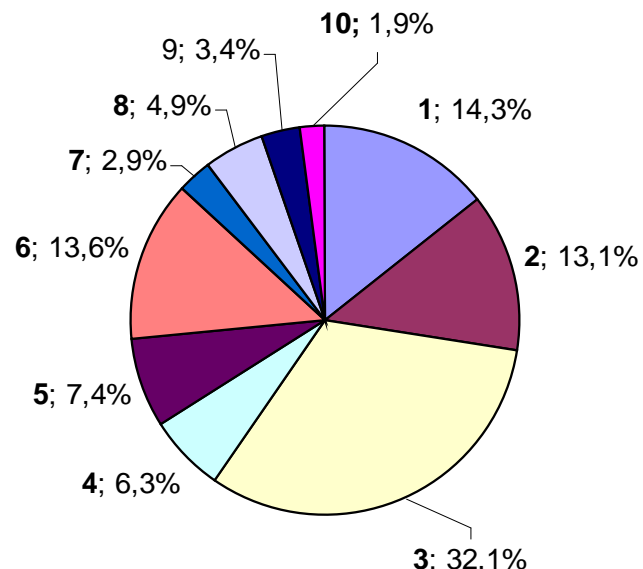

ис. 2. труктур грунтів рп тського регіону кр їни, які використовуються під ріллею: 1 - дерновопідзолисті, у тім числі оглеєні; 2 - сірі лісові, у тім числі оглеєні; 3 - опідзолені грунти, у тім числі оглеєні; 4 - чорноземи, у тім числі к рбон тні; 5 - лучні; 6 - дернові; 7 - буроземно-підзолисті; 8 - бурі гірськолісові; 9 - дерново-буроземні; 10 - інші.

йбільші ч стки розор ності в регіоні м ють опідзолені грунти в ернівецькій $(49,7)$, в но- $р$ нківській $(43,4), \quad$ ьвівській $(2,67)$ обл стях т дернові $(53,6)$ у к рп тській. йменші пок зники розор ності вл стиві гігроморфним т н півгідроморфним грунт м, н віть 3 умови зн чних м сшт бів їхнього осушення, т бурим гірсько-лісовим грунт м рп т, що зумовлено несприятливими для ведення сільського господ рств клім тичними, орогр фічними пок зник ми і їхніми фізико-хімічними вл стивостями (кисл ре кція грунтового розчину, висок гідролітичн кислотність, к м'янистість т ін.).

йв жливіше зн чення грунти як чинник, що зумовлює особливості використ ння земельного фонду, м ють у сільськогоспод рському і лісогоспод рському землекористув $\mathrm{H}$ нi. всіх інших тип х землекористув ння грунт розгляд ють як скЛ дову л ндш фту, що виконує, головно, опорну функцію. жливість і нез мінність грунту в житті людини т функціонув нні біосфери зумовили першочергове використ ння продуктивних грунтів для потреб сільськогоспод рського виробництв, в відведення земельної ділянки під будівництво укр їнське з конод вство зобов'язує знім ти і скл дув ти верхні прогумусов ні горизонти для потреб рекультив ції чи землев ння [7]. вип дку ведення сільськогоспод рського землекористув ння грунти виконують функцію предмет і з собу пр ці, визн ч ють н прям сільськогоспод рського виробництв , спектр культур і рент бельність їхнього вирощув ння. ме 
поширення родючих грунтів, які не потребують зн чних дод ткових витр т н збільшення врож йності основних сільськогоспод рських культур, є в гомим ргументом у домінув нні сільськогоспод рського землекористув ння. меж х рп тського регіону кр їни ре ли н йефективнішого сільськогоспод рського виробництв (рослинництв ) приурочені до природних регіонів 3 н йродючішими грунт ми (чорноземи к рбон тні, темно-сірі опідзолені, чорноземи опідзолені), н йбільші їні ре ли - до пілля, рут- ністерського межиріччя, олинської т янськоністерської височини.

ісогоспод рське землекористув ння передб ч $є$ використ ння лісу і лісових земель для екологічних, експлу т ційних, естетичних і виховних цілей. родуктивність лісових біоценозів є функцією умов місцезрост ння, як може змінюв тися одноч сно зі зміною цих умов. р зі ведення лісового господ рств грунти виконують опорну функцію, з безпечують продуктивність лісових біоценозів, слугують з хисним 6 р'єром від н дмірної ерозії, є регулятором у розподілі тмосферних оп дів. імізм грунту, його фізичні вл стивості, потужність ш ру, доступного для проникнення коріння, вр ховують у р зі визн чення трофогенного ряду типів лісорослинних умов (бори, суббори, сугруди, груди).

фективне використ ння земельних ресурсів у суспільному виробництві є основою економіки кр їни, оскільки, з оцінк ми вітчизняних експертів, близько $95 \%$ обсягу продовольчого фонду кр їни, пон д 2/3 фонду тов рів спожив ння формується н з с д х використ ння земельних ресурсів. ресурсній з безпеченості соці льноекономічного розвитку кр їни земельні ресурси ст новлять пон д $40 \%$, тоді як виробничі т оборотні фонди - пон д 20, трудові ресурси - близько $39 \%$ [9]. собливу роль у сільськогоспод рському землекористув нні відігр є якість грунтів земель, де вони є місцем (просторовим б зисом) орг ніз ції виробництв т його головним з собом. процесі обробітку грунтів земель вони виконують функцію предмет пр ці, оскільки в цьому вип дку пр ця спрямовується безпосередньо н зміну їхнього ст ну і вл стивостей. умови р ціон льного сільськогоспод рського землекористув ння грунти земель не втр ч ють своїх продуктивних вл стивостей, н вП ки, - підвищують родючість. ході р ціон льного землекористув ння грунти земель не мортизуються і мор льно не ст ріють, що є методологічною основою їнього використ ння в сільському господ рстві. од льше н рощув ння сільськогоспод рського виробництв з умови нехтув ння пит нь орг ніз ції території т ролі грунтів неминуче призводить до різкого зрост ння енергетичних витр т у розр хунку н одиницю виробленої продукції, стрімкого зрост ння ризиків швидкого висн ження продуктивності грунтів земель, дегр д ції грол ндш фтів, з бруднення довкілля, 3 гострення проблеми з безпеченості якісною питною водою т ін.

фективність сільськогоспод рського землекористув ння н всіх історичних ет п х вирішув ли винятково з економічних позицій, зн ходячи низькоз тр тний в рі нт використ ння землі, без ур хув ння погіршення якісних пок зників грунтів. кий підхід д в в змогу, з одного боку, обгрунтовув ти позитивні пок зники рент бельності в р зі вирощув ння сільськогоспод рських культур, з зіншого, - сприяв погіршенню вл стивостей грунтів, з лучених у сільськогоспод рське виробництво. сі позитивні результ ти економіки досяг ли вн слідок екологічних втр т. суч сних технологій сільськогоспод рського землекористув ння кількісні т якісні п р метри земельних ресурсів, у тім числі грунтових, погіршув тимуться. етодологічною основою оптиміз ції землекористув ння є концепція економічного зрост ння з одерж нням 
допустимо можливого приросту продукції з умови мінім льних бо нульових екологічних втр т.

тже, домінув ння продуктивних грунтів у суч сних умов х ведення сільського господ рств є основою досягнення позитивних економічних пок зників, оскільки екологічним п р метр м сільськогоспод рського землекористув ння приділяють незн чну ув гу. икорист ння комплексного підходу для оцінки якості сільськогоспод рського землекористув ння н з с д х ур хув ння просторових, пр вових, економічних, екологічних пок зників т їхньої б льної оцінки д ло змогу виявити, що виріш льний вплив н ефективність використ ння земельного фонду у сільському господ рстві м є домінув ння продуктивних грунтів [11]. ому для х р ктеристики сільськогоспод рського землекористув ння доцільно вжив ти термін "грунтокористув ння" т з стосовув ти морфологічні особливості й фізико-хімічні вл стивості грунтів для вр хув ння ефективності їхнього використ ння.

\section{СПИСОК ВИКОРИСТАНОЇ ЛІТЕРАТУРИ}

1. рунти к рп тської обл сті / [з $71 \mathrm{c.}$

2. рунти в но- р нківської обл сті / [з ред. . . к чук]. - жгород : рп ти, 1969. $-77 \mathrm{c}$.

3. рунти ьвівської обл сті / [з ред. . ленчук, . иколин]. - ьвів : меняр, 1969. -84 c.

4. рунти ернівецької обл сті / [3 ред. . . к чук]. - ернівці : уковин , 1969. $71 \mathrm{c.}$

5. урбик . . олочн помір н укр їнських землях у скл ді еликого князівств итовського в VI ст. / . . урбик // кр. іст. журн. - 1996. - № 4. - . 52-59.

6. уцуляк . . емельно-ресурсний потенці л рп тського регіону / . . уцуляк. - ьвів : віт, 1991. - 152 с.

7. емельний кодекс кр їни: омент р. - . : дісей, 2002. -600 с.

8. сторія укр їнського селянств . риси : у 2 т.- . : у ук. думк , 2006. - . 1. $630 \mathrm{c}$.

9. зьмір . . рг ніз ція сільськогоспод рського використ ння земель н л ндш фтно - екологічній основі / . . зьмір, . . тойко, . . роздяк / [3
з г. ред. . . зьмір ]. - ьвів : , 2009. - 254 с.

10. ньків . . волюція землекористув ння в кр їні : моногр фія / . . н ньків. ьвів : ид вн. центр імені в н р нК , 2012. - 188 с.

11. ньків . . етодологічні основи оцінки якості сільськогоспод рського землекористув ння // кр їн : геогр фія цілей т можливостей : зб. н ук. пр ць. - іжин : “ исенко . .”, 2012. - . 1. - .250-252.

12. озняк . . рунтозн вство і геогр фія грунтів : підручник : у 2 ч. / . . озняк. ьвів : імені в н р нк, 2010. - .1.-270 c.; . 2. -286 с.

m ття:н дійшл до ред кцї̈ 25.04.2013

доопр иьов н 28.05.2013

прийнят до друку 17.06.2013 


\title{
PRODUCTIVE SOILS AS BASIS FOR EFFECTIVE AGRICULTURAL LAND USE IN CARPATHIAN REGION OF UKRAINE
}

\author{
Zinovii Pankiv \\ Ivan Franko National University of Lviv, \\ P. Doroshenko St., 41, UA - 79000, Lviv, Ukraine
}

The structure of soils in Carpathian region of Ukraine, which is involved for agricultural land use, including for arable land, has been analyzed. The basic steps to increase the area of arable land have been described. Integrated approach with using spatial, legal, environmental, and economic performance has been proposed for definition of the efficiency of agricultural land use. The appellation "soil use" for characteristic the type using of agricultural land resources has been proposed.

Key words: productive soils, land use, the Carpathian region of Ukraine, soil use.

\section{ИновИй НькИв}

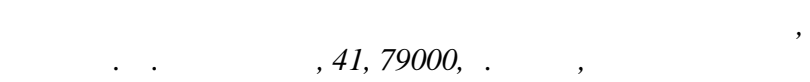

ро н лизиров но структуру почвенного покров рп тского регион кр ины, привлеченного в сельскохозяйственное землепользов ние, в том числе под п шню. ст новлено основные эт пы увеличения площ ди п хотных земель. ля определения эффективности сельскохозяйственного землепользов ния предложено использов ть комплексный подход с использов нием простр нственных, пр вовых, экологических, экономических пок з телей. ля $\mathrm{x}$ р ктеристики сельскохозяйственного тип использов ния земельного фонд обоснов но использов ние термин “почвопользов ние".

лючевые слов : производительные почвы, землепользов ние, рп тский регион кр ины, почвопользов ние. 